る.このうち代表的なものに内分泌性高血圧が あるが，副腎性高血圧が主体であり，原発性ア ルドステロン症 (PA), Cushing症候群 (CS), 褐色細胞腫 (Pheo), などが挙げられる. 近年PA の頻度が従来考えられてきたより多い $(2 \sim 6 \%)$ ことが報告され, 注目されている.PAのスクリー ニング試験としてのアルドステロン/レニン比, 内分泌検査による確認検查, 画像検査および副 腎静脈サンプリング（AVS）による局在診断に よって, 腺腫か過形成の病型を決定してそれぞ れ外科的および薬物治療が選択される。CSは ACTH依存性 (Cushing病 - 異所性ACTH症候群) と非依存性（片側腫瘍・両側過形成）の鑑別診 断から始まる. ACTH依存性CSでは内分泌検査 と画像検査に加えて下錘体静脈サンプリング
(IPSS)やオクトレオチドシンチが有用である. Cushing病の治療の第一選択は下垂体腺腫摘出術 であり, 異所性ACTH産生腫瘍では原発巣の腫 瘍摘出術（可能なら）である。手術不能例ある いは再発例には放射線や薬物治療が選択される. ACTH非依存性CSでは副腎腺腫によるものは診 断と治療は比較的容易である. しかし subclinical CSを呈する腺腫や結節性過形成の外科的治療は 必ずしも確立されたものではない. Pheoの診断 は内分泌検査（カテコールアミン測定）と各種 画像検查により比較的容易である。しかし近年 SDHB変異による副腎外Pheo(パラガングリオー マ）や転移・再発を呈する悪性Pheoの診断と治 療の取り扱いが問題となっている。

\title{
15. 免疫性末梢神経障害の病態と治療：Guillain-Barré症候群を中心に
}

\section{千葉大学神経内科 桑原聡}

免疫性末梢神経障害は末梢神経の構成成分を 標的分子として自己免疫機序により発症する ニューロパチーの総称である. 障害神経線維 (運 動・感覚・自律神経) と発症様式 (急性・慢性) により分類がなされている.代表的疾患はGuillainBarré症候群（GBS）であり，急性の運動優位多 発ニューロパチーを呈する。年間発症率は 10 万人に 1 2 人とされ, 先進国における急性四肢 麻痺の原因として最も頻度が高い. 1916 年の原 著報告以来, 本症候群は長らく髄鞘を標的とす る脱髄性ニューロパチーとされてきたが, 1990 年代に入り軸索が一次性に障害される軸索型GBS の存在が確立された. その後, 軸索型GBSは東ア ジア (中国, 日本) で頻度が高いこと, キャン ピロバクター腸炎が先行することが多いこと， 高頻度に血清抗ガングリオシド自己抗体が認め られることが明らかになった。これらの事実か ら「ヒト神経系ガングリオシドとキャンピロバ
クター外膜に発現するリポオリゴ糖との分子相 同性」による発症機序が確立されるに至った。

ある自己免疫疾患が分子相同性によって発症 することを証明するためには以下の 4 条件を満 たすことが必要である：(1) 微生物感染と疾患 発症の間に疫学的関係が存在すること，(2) 自 己抗体が同定されること, (3) 微生物とヒト標 的抗原の間に分子相同性が存在すること, (4) 微 生物・標的分子の感作により動物モデルが樹立 されること. 2001 年にガングリオシドGM1 の能 動免疫により疾患モデルが樹立されたことで, 軸索型GBSはこれらの 4 条件を満たす初めての自 己免疫疾患となった．治療法として血漿交換と 免疫グロブリン大量静注療法の有効性は確立さ れているが, これらの治療を行っても 20〜30\% の患者において重度後遺症が認められ，さらな る治療法の開発が望まれる。動物モデルで補体 介在性の組織障害が明らかにされていることか 
ら, 補体阻害薬が次世代の治療法として期待される.

\title{
16. 消化器内視鏡治療の現状と展望
}

\author{
東京慈恵会医科大学消化器 - 肝臟内科 田尻 久雄
}

内視鏡を用いた初期の本格的な治療として, わが国で 1968 年に胃ポリープ切除術が報告され ている. 1980 年代には平坦〜陥凹病変でも切除 可能な手技として内視鏡的粘膜切除術切除 （EMR）が開発された。 1990 年代になると内視 鏡先端にフードを装着して平坦〜陥凹病変をフー ド内に吸引して切除する吸引法が開発された。 これらの手技は簡便であるが, 1 回で切除できる 範囲が限られ, 大きな病変では分割切除となる ため病理学的検索が不確実となり, また遺残・ 再発という問題が残された.そこで 1990 年代後 半から 2000 年代に入り, 内視鏡的粘膜下層剥離 術（ESD）が登場して瞬く間に普及し, 食道・ 胃腫瘍ではすでに保険収載されている。 さらに 体表面に傷が残らない夢の低侵襲手術として, 近年注目を集めている新しい治療概念がNOTES (Natural Orifice Translumenal Endoscopic Surgery）である. 皮膚を切開し, 体腔内へ到達す る従来の外科手術とは異なり, 軟性内視鏡を用 いてロや肚門から消化管経由で, さらには腟な
どを経由して, 壁を穿孔させた後に腹腔内や胸 腔内へと到達し，手技を行う。わが国では 2005 年に日本消化器内視鏡学会と日本内視鏡外科学 会によるNOTES二学会合同委員会が立ちあげら れ，2007 年にはNOTES研究会 (Japan NOTES) が設立された。臨床応用と同時に技術的課題が 明確になり, その解決に向けて機器開発競争に も拍車がかかっている. 低侵襲性, 疼痛の軽減, 入院期間の短縮, 医療費の削減は, 患者にとっ ても医療界の将来にとっても分野を問わず重要 なテーマである. ESD, NOTES関連手技はいず れも高度な技術を要するが，これらの課題を解 決するための有望な手段である。われわれは, $\mathrm{EMR} / \mathrm{ESD}$ で培ってきた技術を応用し, 消化管腫 瘍の内視鏡的全層切除術, 消化管深部とくに筋 層の内視鏡的超拡大観察, 内視鏡的分子イメー ジング研究に関する取組みを開始している．今 後, 内科・外科という枠を越えて内視鏡治療分 野が飛躍的に発展することが期待される.

\section{7. 骨髄不全症の診断と治療}

\section{自治医科大学内科学講座血液学部門 小澤 敬也}

慢性骨髄不全症には, 再生不良性貧血（再不 貧） - 骨骾異形成症候群（MDS）・後天性溶血 性貧血 [発作性夜間へモグロビン尿症 $(\mathrm{PNH})$ 及 び自己免疫性溶血性貧血(AIHA) ] 原発性骨髄 線維症 $(\mathrm{PMF})$ などが含まれる。厚労省の特発 性造血障害調査研究班では, これらの疾患の診
断基準と重症度基準を策定し，さらに治療方針 などを加えて「診療の参照ガイド」としてまと めている，再不貧と不応性貧血（MDS-RA）は 鑑別がしばしば困難であるが, 形態異常の有無 がポイントとなる，再不貧の治療に関しては, 免疫抑制療法と造血幹細胞移植が主なものであ 